\title{
PROMOTIONAL TOOLS - A CATALYST TO SPEED UP SALES
}

\section{Isra Khan ${ }^{1}$ and Usman Ali Warraich ${ }^{2}$}

\begin{abstract}
Marketers all over the world try to find creative strategies to attract customers, promotional tools are one important aspect of this paradigm. Sales teams use promotional tools to influence the customers and entice their purchase behaviour. The aim of the study was to formulate a technique that has a significant positive impact and motivates the consumer to buy a certain product during the sales season. Four promotional tools were studied and analysed to construe their relationship with consumer's buying behaviour. The study is quantitative in nature, and the data for the study were collected from 300 customer respondents through convenient sampling. Regression analyses were employed through SPPSS to analyze the data. The results have concluded that the price discount has a positive impact on a consumer's mind and that makes him buy a product more. This study will help marketing managers and decision-makers in the sales team to strategize efficient marketing campaigns.
\end{abstract}

Keywords: Sales Promotion; Marketing Strategies; Discounts; Sale, Consumer Buying Behaviour.

\section{INTRODUCTION}

Marketers have long used sales promotions as a tool to catalyze sales and attract consumers for years now to pull customers to supermarkets and boost short-run sales volume. An organization needs to introduce different promotional activities to ensure that its brand is the talk of the town. In order to do so, a sales promotion tool is used to attract new consumers and also to keep existing consumers engaged. Sales promotion works on the psychological mechanism of consumers. The idea is thus to use these tools to maximize sales.

Monetary promotional tools are price discounts and coupons. These are the most common tools used by organizations. However, the trend regarding non-monetary promotions, for example, free

\footnotetext{
${ }^{1}$ Student, Institute of Business Management, Karachi, Pakistan.

${ }^{2}$ Visiting Faculty, Institute of Business Management, Karachi, Pakistan.
} 
gifts, free samples, games, and sweepstakes, are getting popular among consumers, it is also leaving a negative impact on the brand image due to frequent discounts. Such promotional tools are projected to enhance the worth of product purchases by either decreasing the cost of the product or by added benefits (such as Buy 1 Get 1 Free, free samples) to the regular price. In all the previous researches, sales promotion is seen as a momentary and tangible modification of supplies to achieve the goal, i.e., direct impact on consumer's buying behaviour. This study thus intends to find answers to the following questions:

- What is the impact of the coupons used to boost sales in order to observe consumer's buying behaviour?

- What is the impact of discounted prices used to boost sales in order to observe consumer's buying behaviour?

- What is the impact of sweepstakes and games used to boost sales in order to observe consumer's buying behaviour?

- What is the impact of B1G1F used to boost sales in order to observe consumer's buying behaviour?

\section{STATEMENT OF THE PROBLEM}

Advertising in this era is easier than in earlier times. It is used to motivate people through a videotape or a catchy caption that compels them to buy a certain product. The final goal of advertising is not entirely to make a sale. On some occasions, it is used to build up a perspective in a consumer's mind when the product is not even launched. Although sales promotion is direct and not meant to hide the ultimate goal, i.e., make a sale.

Familmaleki (2015) posits that organizations allocate about $75 \%$ of their marketing communication budget to sales promotion in order to influence consumer behaviour.

The main reason behind this is to integrate the total marketing strategy in organizations as it is introduced at the inauguration of a campaign as it is against tackling changes (post-sales season) in the marketing environment which reveals upward pressure on the need for sales promotion (Adewale et al., 2013). It is a campaign that is carried out for a specific time frame, a place or group of potential buyers, to inspire a direct response from consumers or retailers, through the offer of added benefits (Peattie \& Peattie, 1994). Promotions are offered directly to consumers by marketers as they are designed to motivate the consumer for impulsive buying. In this study, the 
impact of different promotional tools is studied on consumer's buying behaviour. The study is conducted on four promotional tools so it can be concluded which tool is most effective to increase sales.

\section{RESEARCH MODEL}

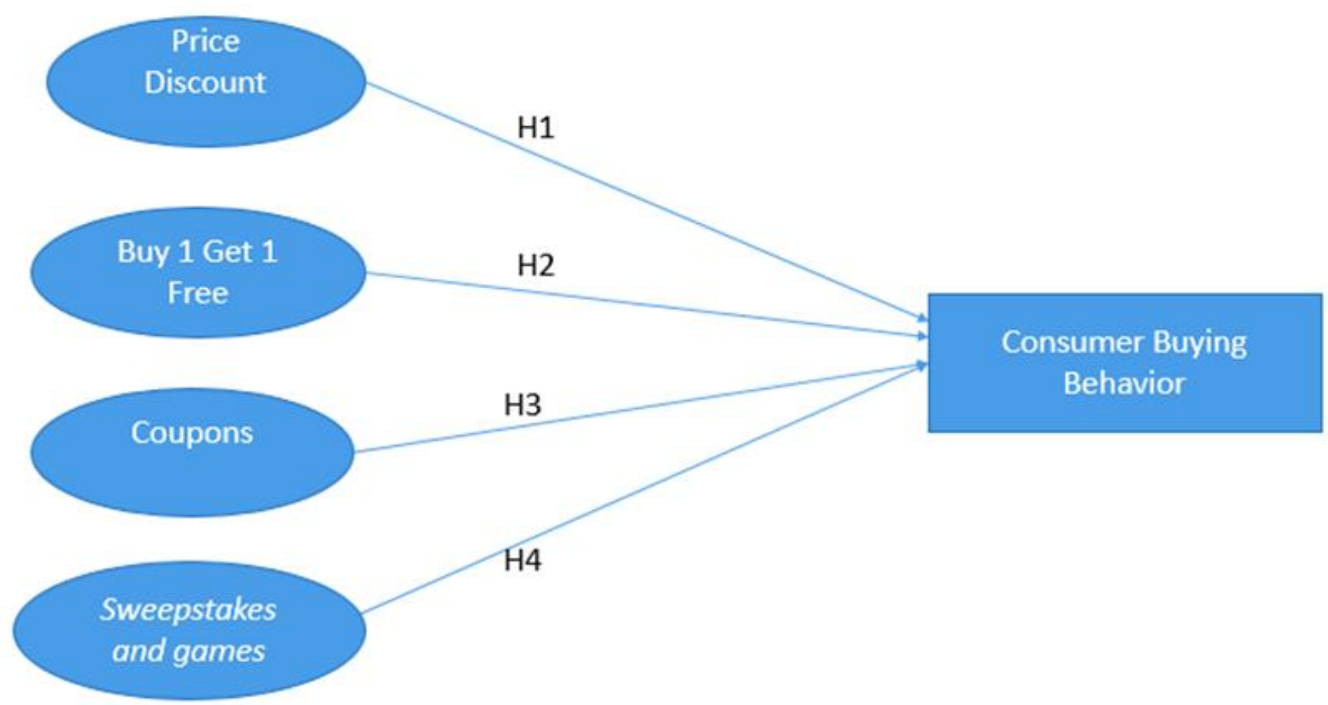

\section{RESEARCH HYPOTHESIS}

H1: Price Discounts has a significant positive relationship with consumer buying behaviour.

H2: Coupons has a significant positive relationship with consumer buying behaviour.

H3: Buy 1 get 1 Free has a significant positive relationship with consumer buying behaviour.

H4: Sweepstakes and games have a significant positive relationship with consumer buying behaviour. 
Journal of Marketing Strategies, Volume 3, Issue 2, May 2021

\begin{tabular}{|c|c|c|c|}
\hline S.no & Hypothesis & Citation & Article \\
\hline \multirow{6}{*}{ 1- } & \multirow{6}{*}{$\begin{array}{l}\text { H1: Price Discounts has significant } \\
\text { positive relationship towards } \\
\text { consumer buying behaviour }\end{array}$} & (Khan, 2019) & $\begin{array}{l}\text { IMPACT OF SALES PROMOTION ON CONSUMER BUYING BEHAVIOR: A CASE OF } \\
\text { MODERN TRADE, PAKISTAN }\end{array}$ \\
\hline & & (Keyan \& Natarajan, 2019) & Impact of Sales Promotion Techniques on Consumers towards FMCG \\
\hline & & (Shamout, 2016) & The Impact of Promotional Tools on Consumer Buying Behavior in Retail Market. \\
\hline & & (Shi et al., 2005) & Behavioural response to sales promotion tools \\
\hline & & (Ahmad et al., 2015) & Impact of Sales Promotion on consumer buying behavior in Pakistan \\
\hline & & (Samreen et al., 2020) & The Impact of Sales Promotion on Consumer Buying Behavior \\
\hline \multirow{8}{*}{$2-$} & \multirow{8}{*}{$\begin{array}{l}\text { H2: Coupons has significant positive } \\
\text { relationship towards consumer buying } \\
\text { behaviour }\end{array}$} & (Khan, 2019) & $\begin{array}{l}\text { IMPACT OF SALES PROMOTION ON CONSUMER BUYING BEHAVIOR: A CASE OF } \\
\text { MODERN TRADE, PAKISTAN }\end{array}$ \\
\hline & & (Keyan \& Natarajan, 2019) & Impact of Sales Promotion Techniques on Consumers towards FMCG \\
\hline & & \multirow{2}{*}{ (Mughal et al., 2014) } & The Impact of Promotional Tools on Consumer Buying \\
\hline & & & Behaviour: A Study from Pakistan \\
\hline & & (Shamout, 2016) & The Impact of Promotional Tools on Consumer Buying Behavior in Retail Market \\
\hline & & \multirow{2}{*}{ (Ahmad et al., 2015) } & Impact of Sales Promotion on consumer buying \\
\hline & & & Behavior in Pakistan \\
\hline & & $($ Samreen et al., 2020) & The Impact of Sales Promotion on Consumer Buying Behavior \\
\hline \multirow{7}{*}{$3-$} & \multirow{7}{*}{$\begin{array}{c}\text { H3: Buy } 1 \text { Get } 1 \text { Free has significant } \\
\text { positive relationship towards consumer } \\
\text { buying behaviour }\end{array}$} & (Khan, 2019) & IMPACT OF SALES PROMOTION ON CONSUMER BUYING BEHAVIOR: ACASEOF \\
\hline & & (Keyan \& Natarajan, 2019) & Impact of Sales Promotion Techniques on Consumers towards FMCG \\
\hline & & (Shamout, 2016) & The Impact of Promotional Tools on Consumer Buying Behavior in Retail Market. \\
\hline & & (Shi et al., 2005) & Behavioural response to sales promotion tools \\
\hline & & & promotion tools \\
\hline & & (Ahmad et al., 2015 & Impact of Sales Promotion on consumer buying \\
\hline & & & behavior in Pakistan \\
\hline \multirow{5}{*}{4} & \multirow{5}{*}{$\begin{array}{c}\text { H4: Sweepstakes and games has } \\
\text { positive relationship towards consumer } \\
\text { buying behaviour }\end{array}$} & (Keyan \& Natarajan, 2019) & Impact of Sales Promotion Techniques on Consumers towards FMCG \\
\hline & & \multirow{2}{*}{ (Shi et al., 2005) } & Behavioural response to sales \\
\hline & & & promotion tools \\
\hline & & (Obeid, 2014) & The effect of sales promotion tools on behavioral responses \\
\hline & & (Nakarmi, 2018) & $\begin{array}{l}\text { EFFECT OF SALES PROMOTION ON CONSUMER BUYING BEHAVIOUR: IN CASE OF } \\
\text { COCA COLA SOFT DRINK, BAHIR DAR CITY }\end{array}$ \\
\hline
\end{tabular}

\section{LITERATURE REVIEW}

\section{Sales promotions and its tools}

Sales promotion is mainly a marketing activity and the reason to initiate these customer focussed activities are to recognise the buying behaviour of the product's consumers. Sales promotion is subdivided into 3 subcategories: consumer promotions; retailer promotions; and trade promotions. 
Sales promotion means any activity that is utilized by the producer to give confidence to the trade (retailer, wholesaler, or network associates) as well as make customers purchase a brand and boost up a sales force to assertively sell it. The term sale promotion refers to several types of selling incentives and methods concave to yield immediate sales effects (Totten \& Block, 1994) The tools of sales promotion are mostly effective for marketing that is subjected to consumers. Marketers use this technique when they have to target a large number of consumers or promotions that are trade-oriented. The firm's marketing department conducts such activities and the reason to initiate these customers focussed activities are to recognise the buying behaviour of the product's consumers. Kojima and Baba (2001) have stated that consumer behaviour can also be observed as a utility and activities for value addition.

Promotional campaigns attract consumers that are prone to promotions and are usually looking to try new products. These consumers will be attracted to a brand that is offering discounted rates for a limited period of time. It has been seen as a trend that many promising consumers even change brands to receive a good deal on a promotional campaign. These campaigns attract consumers regardless of being faithful to a brand. This even makes them migrate to a new brand that has more to offer and is always present in a market with innovative promotional ideas. Retailers and manufacturers all over the world use promotion as a tool to attract potential consumers to buy their products or avail their services (Mughal et al., 2014).

Few previous research concludes that discount on price has no significant impact on the volume of particular purchases by a consumer (Ahmad et al., 2015). It is a unique tool that can be used efficiently by Marketers for the increment of sales significantly (Ali, Ahmed; Al Karim, 2017). There are various techniques said to be short term promotional techniques. These are designed to involve consumers so they may respond differently. Sales promotion hits directly to product purchasing by consumers. These techniques mostly reduce the cost of an item that the seller wants to make the sale for or giving an added benefit for this matter. Promotional techniques help to ensure brand awareness and create brand loyalty amongst customers (Raji, Rashid, \& Ishak, 2019). A market has a variety of tools to use for its promotional campaign; generally, the following techniques are used: 


\section{Price Discounts}

Price discount is categorised to be a valuation approach; here goods and services are set to be at a discounted rate. The strategy here is to make the sale at the point of purchase or at the hypermarkets to attract the masses (Shamout, 2016). Marketer's set a reduced cost to target consumer's loyalty towards the brand, ensuring they do not switch to alternate brands priced cheaply. Most retailers often promote combinations of price reduction in order to get the favourable assessment related to prices and buying trends of consumers. Discounts summarise potentially for clarifying the consumer response to sales promotion (e.g., Dickson \& Sawyer, 1984; Blattberg \& Neslin, 1990). Previous studies stress upon the fact that reduced prices attract potential consumers that were already using some other brand (Fill, 2002; Bryman, 1994). Sales during "peak season" mostly attract regular customers rather than new ones. New customers who are attracted during sales season are lost in the regular season as they go back to the brand they were using originally (Ehrenberg et al, 1994). Price discount is the most used for the promotional campaign, the discount is mentioned on the price tag or on the display cabinet of shops and stores (Shahzad et al., 2020).

\section{Coupons}

Coupons are one way of advertising, used to engage customers who won vouchers on any deals. They have been used for promotional purposes, to introduce a new product or change the mind of the consumer for many years now (Gardener \& Trivedi, 1998). Consumers become eligible to get an allowance on the associated product (Ndubisi \& Moi, 2006).

Coupons are certificates and vouchers that make a customer to gain price reduction on that specific product. The discounted value or the stated price cut is mentioned on the coupon, the customer is supposed to show the coupon at the time of the purchase. Having a coupon as a sales promotion technique, marketers with a new brand can easily introduce their brand for trial purchase. Using a coupon as a promotional team has helped manufacturers build a relationship with their consumers (Ahmad et al., 2015). The trend seen with coupons has proven that using this promotional tool does not motivate consumers to purchase a product in huge volume (Gilbert \& Jackaria, 2002).

Coupons are easy to understand and have always made consumers switch brands because of an offer they cannot refuse. Consumer's buying behaviour is mostly influenced by coupons (Bhutada, Cook, \& Perri, 2009). Many researchers in the past have concluded that coupons can portray a 
negative impression on a brand image, considering a huge reduction in the price. This may influence negatively on a product trial (Silva-Risso \& Bucklin, 2004).

\section{Buy One Get One Free (BOGOF)}

BOGG or B1G1F is a bonus package which let consumer buy 2 units of a product at a price of one. This technique attracts consumers psychologically and makes them purchase a product which they were not even willing to buy. It is usually written in bold, "Buy 2 at a price of one", which itself attract a new and existing consumer, consequently helping to boost up sales. Moreover, this tool is beneficial to retailers SALE speed as compared to price promotion ( $\mathrm{Li}$, Sun, and Wang, 2007).

\section{Sweepstakes and Games}

Sweepstakes and games are commonly known to everyone as "lucky draws." This technique is used by marketer's, supermarket's retailers to attract traffic. Consumers take part in these games for perceived fun and interest (Ward \& Hill 1991). Although this particular technique has received little attention from researchers, sweepstakes and games are the most popular ways to attract consumers in Hong Kong (Shi et al., 2005).

\section{RESEARCH METHODOLOGY}

\section{Research Design}

The research design used is descriptive analysis to investigate to study the thorough picture of the situation. Moreover, it involves a detailed description of all the findings in the form of a table. This helped in developing inferences amongst the two variables, i.e., the "sales promotional tools" and “consumer buying behaviour." Explanatory research was used as it enriches the previous studies. This will support previous theories by comparing the findings through research questions. The observed phenomenon, problems, behaviour, and findings are explained in explanatory research (Kothari, 2004). As the above reasoning supports, this study will have both, descriptive and explanatory types.

\section{Research Approach}

The research approach used is the deductive approach. This theory is already in existence before and studied many times. It is a quantitative study. Research is formulated to analyse the collected data to study the independent variables and their impact on dependent variables. The research 
includes sampling techniques and the statistical technique that was employed during the study. Moreover, in this study, mono-method research is used. It is when the data collected is qualitative or quantitative. The research is expected to be generalised as this is a quantitative study.

\section{Research Objectives}

This study will help conclude which independent variable has a significant positive impact on the dependent variable. The configuration of this research will help examine promotional tools and their various advantages. This research, being quantitative will help to understand the positive impact of each variable.

\section{Research Technique}

The data was collected primarily from people of different professional groups, different gender, age, income groups. The form was circulated in different groups of employed individuals. The Likert scale used was from 1 to 7 where the level of Agreement was defined as 1 - Strongly disagree, 2 - Disagree, 3 - Somewhat disagree, 4 - Neither agree nor disagree, 5 - Somewhat agree, 6 - Agree, 7 - Strongly agree. Out of 300 respondents, 109 responded, at this point, the questionnaire was withheld, and data was extracted to be analysed.

\section{Sampling Design and Technique}

A sample is a portion of the population one has selected, and a sampling unit is one respondent from the sample. In this study, the questionnaire was floated in the group of educated and employed individuals. Researchers have used non-probability sampling or convenience sampling techniques. It is based on collecting data from respondents conveniently. The questionnaire was made simple, and no identity was required so the respondents do not find it inconvenient to fill the form. The sample is explained as a set that consists of elements that are selected through certain considerations from a population (Schofield, 1996). 108 is the sample size of this study employed from a population of 300 employed individuals.

\section{STATISTICAL TESTING}

Before the data was processed, the data exported through the questionnaire was sorted and thoroughly checked and it was also edited for consistency. The data was then grouped into different categories. The second phase was to make it readable for SPSS i.e., the software used for analysis. Statistical Package for Social Science (SPSS) software version 25. 


\section{Construct Reliability}

Reliability is the tool i.e., significant for minimizing faults that may arise in measuring difficulties in research. This test indicates that your research is random error-free. The research is reliable, and respondents have filled the questionnaire with complete assistance. The questionnaire reliability is tested through Cronbach's Alpha. Conventionally, the Alpha is 0.7 or higher is accepted, the same thing is being considered in this research.

Table 1. Construct Reliability

\begin{tabular}{|c|c|c|c|}
\hline Serial No. & Construct & Cronbach's Alpha & No. of items \\
\hline 1 & Price Discount & 0.605 & 4 \\
\hline 2 & Coupons & 0.708 & 5 \\
\hline 3 & Sweepstakes or Games & 0.890 & 5 \\
\hline 4 & Buy One Get One Free (B1G1F) & 0.880 & 5 \\
\hline 5 & Consumer's Buying Behavior & 0.961 & 5 \\
\hline
\end{tabular}

Source: Study Analysis

The above table summarises that price discount Cronbach' Alpha for the mentioned variables all has values above 0.7, except for price discount. The data suggest that the questionnaire is reliable.

\section{Descriptive Statistics}

This tool was used to analyse the result of demographic and overall. In the result section frequency distribution and its percentage table is presented.

Table 2. Descriptive Statistics

Descriptive Statistics

\begin{tabular}{|l|r|r|r|r|r|}
\hline & \multicolumn{1}{|c|}{$\mathrm{N}$} & Minimum & Maximum & \multicolumn{1}{l|}{ Mean } & Std. Deviation \\
\hline Price_Discount & 108 & 1.80 & 7.00 & 4.9593 & 1.13360 \\
Coupon & 108 & 1.00 & 6.60 & 4.1778 & 1.39058 \\
B1G1F & 108 & 1.00 & 7.00 & 4.5333 & 1.46562 \\
Sweepstakesorgames & 108 & 1.00 & 7.00 & 3.6704 & 1.68364 \\
Consumer_Behaviour & 108 & 2.50 & 5.50 & 4.1235 & .69605 \\
Valid N (listwise) & 108 & & & & \\
\hline
\end{tabular}

\section{Interpretation and Explanation:}

1- A value of 0.00 correlation does not represent any relationship.

2- The value of -1 correlation concludes a perfect negative relationship.

3- The value of +1 correlation concludes a perfect positive relationship. 
The above table 2 summarises the data gathered for the study; sales promotional tools impact on buying behaviour of consumers.

1- People who prefer price discount as a sales promotional tool are given a mean score of 4.95

2- People who prefer coupons as a sales promotional tool are given a mean score of 4.17

3- People who prefer B1G1F as a sales promotional tool are given a mean score of 4.53

4- People who prefer Sweepstakes or games as a sales promotional tool are given a mean score of 3.67

The data above shows it is possible to summarize that the mean and standard deviation of every variable has the level of agreement of every respondent for the idea requested in the questionnaire.

Table 3.

\begin{tabular}{|c|c|}
\hline Correlation coefficient & Description \\
\hline $0.70-1.00$ & Very strong association \\
\hline $0.50-0.69$ & Substantial association \\
\hline $0.30-0.49$ & Moderate association \\
\hline $0.10-0.29$ & Negligible association \\
\hline
\end{tabular}

Source: Analysis

\section{Inferential Analysis}

Table 4. Correlations - Effect of Sales promotional tool of consumer buying behaviour Correlations

\begin{tabular}{|c|c|c|c|c|c|c|}
\hline & & $\begin{array}{c}\text { Consumer_B } \\
\text { ehaviour }\end{array}$ & $\begin{array}{c}\text { Price_Discou } \\
\text { nt }\end{array}$ & Coupon & B1G1F & $\begin{array}{c}\text { Sweepstakes } \\
\text { orgames }\end{array}$ \\
\hline \multirow[t]{3}{*}{ Consumer_Behaviour } & Pearson Correlation & 1 & $.246^{\prime}$ & .124 & .166 & .051 \\
\hline & Sig. (2-tailed) & & .010 & .201 & .085 & .603 \\
\hline & $\mathrm{N}$ & 108 & 108 & 108 & 108 & 108 \\
\hline \multirow[t]{3}{*}{ Price_Discount } & Pearson Correlation & $.246^{\star}$ & 1 & $.564^{\mathrm{x}}$ & $.634^{\mathrm{x}}$ & $.450^{\circ}$ \\
\hline & Sig. (2-tailed) & .010 & & .000 & .000 & .000 \\
\hline & $\mathrm{N}$ & 108 & 108 & 108 & 108 & 108 \\
\hline \multirow[t]{3}{*}{ Coupon } & Pearson Correlation & .124 & $.564^{m}$ & 1 & $.697^{m}$ & $.622^{\mathrm{N}}$ \\
\hline & Sig. (2-tailed) & .201 & .000 & & .000 & .000 \\
\hline & $\mathrm{N}$ & 108 & 108 & 108 & 108 & 108 \\
\hline \multirow[t]{3}{*}{ B1G1F } & Pearson Correlation & .166 & $.634^{m}$ & $.697^{\mathrm{N}}$ & 1 & $.632^{\infty}$ \\
\hline & Sig. (2-tailed) & .085 & .000 & .000 & & .000 \\
\hline & $\mathrm{N}$ & 108 & 108 & 108 & 108 & 108 \\
\hline \multirow[t]{3}{*}{ Sweepstakesorgames } & Pearson Correlation & .051 & $.450^{\mathrm{m}}$ & $.622^{m}$ & $.632^{\mathrm{m}}$ & 1 \\
\hline & Sig. (2-tailed) & .603 & .000 & .000 & .000 & \\
\hline & $N$ & 108 & 108 & 108 & 108 & 108 \\
\hline
\end{tabular}

*. Correlation is significant at the 0.05 level (2-tailed).

**. Correlation is significant at the 0.01 level (2-tailed).

Source: Data Analysis of this Study 
The above data shows that the variables are co-related. It can be concluded that these variables are clearly positively related. Suggesting that each independent variable is highly correlated with the dependent variable.

\section{Regression Analysis}

The regression analysis is done to study the value of the coefficient for the independent variable that how much or do they even have any impact on the dependent variable. The researchers have applied regression analysis to the collected data.

Model Summary
\begin{tabular}{|c|c|r|r|r|}
\hline Model & R & R Square & $\begin{array}{c}\text { Adjusted R } \\
\text { Square }\end{array}$ & $\begin{array}{c}\text { Std. Error of } \\
\text { the Estimate }\end{array}$ \\
\hline 1 & $.261^{\text {a }}$ & .068 & .032 & .68494 \\
\hline
\end{tabular}
a. Predictors: (Constant), Sweepstakesorgames,
Price_Discount, Coupon, B1G1F

The above table shows the summary of the model studied; the value of $\mathrm{R}$ is 0.261 i.e., 26.1 percent which shows the percentage of correlation amongst these variables. The coefficient of determination $\mathrm{R}^{\wedge} 2$ suggests how good the model is. In the above case, it is 0.068 , which means when each independent variables changes, it equally changes the dependent variable (consumer behaviour) $6.8 \%$.

\begin{tabular}{|c|c|c|c|c|c|c|}
\hline \multicolumn{7}{|c|}{ ANOVA $^{a}$} \\
\hline \multicolumn{2}{|c|}{ Model } & $\begin{array}{l}\text { Sum of } \\
\text { Squares }\end{array}$ & df & Mean Square & $\mathrm{F}$ & Sig. \\
\hline \multirow[t]{3}{*}{1} & Regression & 3.519 & 4 & .880 & 1.875 & $.120^{\mathrm{b}}$ \\
\hline & Residual & 48.321 & 103 & .469 & & \\
\hline & Total & 51.840 & 107 & & & \\
\hline
\end{tabular}

a. Dependent Variable: Consumer_Behaviour

b. Predictors: (Constant), Sweepstakesorgames, Price_Discount, Coupon, B1G1F

The above table i.e., ANOVA gives overall information and the significance of the model.

- The value of cut off for F- test is 4 , although in the above table it is 1.875 .

- The sig value is greater than 0.05 , which means that the overall model does not have a positive significant impact on the dependent variable. The sig value is 1.20. 


\begin{tabular}{|c|c|c|c|c|c|c|}
\hline \multicolumn{7}{|c|}{ Coefficients $^{a}$} \\
\hline \multirow[b]{2}{*}{ Model } & & \multicolumn{2}{|c|}{ Unstandardized Coefficients } & \multirow{2}{*}{$\begin{array}{c}\text { Standardized } \\
\text { Coefficients } \\
\text { Beta } \\
\end{array}$} & \multirow[b]{2}{*}{$t$} & \multirow[b]{2}{*}{ Sig. } \\
\hline & & B & Std. Error & & & \\
\hline \multirow[t]{5}{*}{1} & (Constant) & 3.374 & .300 & & 11.234 & .000 \\
\hline & Price_Discount & .150 & .077 & .244 & 1.936 & .056 \\
\hline & Coupon & -.002 & .072 & -.004 & -.025 & .980 \\
\hline & $\mathrm{B1G1F}$ & .040 & .073 & .083 & .544 & .588 \\
\hline & Sweepstakesorgames & -.045 & .054 & -.110 & -.845 & .400 \\
\hline
\end{tabular}

a. Dependent Variable: Consumer_Behaviour

The table above concludes the significance of all the independent variables over the dependent variable to determine their significance. The unstandardized coefficients for the above independent variables represent the magnitude and relationship of influence on the dependent variable. The positive value of unstandardized coefficients shows that it has a positive impact on consumer buying behaviour. This means that only price discount and B1G1F do have a positive impact on the independent variable. The sig value should be less than 0.05 that will suggest a positive significant relationship on the consumer buying behaviour. The above table shows that only "Price Discount" has a significant positive relationship with consumer behaviour.

The above table 7 has also helped to form the regression equation:

$$
Y=b 0+b 1 X 1+b 2 X 2+b 3 X 3+b 4 X 4
$$

Where: Y is consumer Buying Behaviour; X1: Price Discount; X2: Coupons; X3: B1G1F; X4:

Sweepstakes or games. The equation for the Influence of Sales promotional tools over consumer buying behaviour is as below:

$$
Y=3.374+0.15 X 1+0.04 X 3
$$

\section{Hypothesis Assessment Summary}

\begin{tabular}{|c|l|l|l|}
\hline Hypotheses & Statement & Sig. Value & Decision \\
\hline H1 & $\begin{array}{l}\text { Price Discounts has a significant positive } \\
\text { relationship with consumer buying } \\
\text { behaviour }\end{array}$ & 0.056 & Accept \\
\hline H2 & $\begin{array}{l}\text { Coupons have a significant positive } \\
\text { relationship with consumer buying } \\
\text { behaviour }\end{array}$ & 0.980 & Reject \\
\hline
\end{tabular}




\begin{tabular}{|c|l|l|l|}
\hline H3 & $\begin{array}{l}\text { Buy 1 get 1 Free has a significant } \\
\text { positive relationship with consumer } \\
\text { buying behaviour }\end{array}$ & 0.588 & Reject \\
\hline H4 & $\begin{array}{l}\text { Sweepstakes and games have a } \\
\text { significant positive relationship with } \\
\text { consumer buying behaviour. }\end{array}$ & 0.400 & Reject \\
\hline
\end{tabular}

\section{DISCUSSION AND CONCLUSION}

The four promotional tools were studied and analysed to study their relationship with consumer's buying behaviour. The study aimed to formulate the technique which has a significant positive impact and motivates the consumer to buy a certain product during the sales season. The results have concluded that the price discount has a positive impact on a consumer's mind and that makes him buy a product more (here $\mathrm{t}=1.936$, and $\mathrm{p}=0.056$ ).

According to the text that is studied, most of the results have shown a significant positive impact on buying behaviour. But in many cases coupons, sweepstakes or games did not have any positive impact on the dependent variable studied. This means that coupons do not strongly boost up the sales process. However, price discount unanimously wins over all the other promotional tools. Market's all over Pakistan use this promotional tool to influence the big sales season. Customers will always give a hundred percent attention to the discount sign.

The findings reveal that only price discount has a significant positive impact on buying behaviour of the consumer. It is revealed that the other independent variables do not catch the attention of the buyer during the sales season and do not have a significant positive impact on the dependent variable.

\section{FUTURE RESEARCH DIMENSIONS}

Other promotional techniques should also be tested and researched along with these independent variables in order to figure out that while having the option of a promotional tool. This may change the possibility of the significance of the existing price discount to work with. Researchers also had limited access due to COVID-19 or this questionnaire could have been circulated in supermarkets to genuinely have an audience who shop more. Lastly, other mediating factors should also be used to investigate the impact of occasions on events on sales promotions, for example, events like Ramadan, Eid, Christmas and other occasions. 


\section{REFERENCES}

Adewale, G., Adesola, M. A., \& Oyewale, I. O. (2013). Impact of marketing strategy on business performance: a study of selected small and medium enterprises (SEMS) in Oluyle local government, Ibadan, Nigeria. J. Bus. Manage, 11(4), 59-66.

Ahmad, S. A., Mehmood, W., Ahmed, S. A., Mustafa, M., Khan, M. F. T., \& Yasmeen, M. (2015). Impact of Sales Promotion on consumer buying behavior in Pakistan. International Interdisciplinary Journal of Scholarly Research, 1(3), 13-22.

Ali, M. M., Ahmed, S., \& Al Karim, R. (2017). Impact of Sales Promotion Strategies on Consumer Purchase Decisions in Bangladeshi Chain Superstores.

Ali, A., \& Muhammad, K. (2021). Impact of Promotional Tools on Consumer Buying Behavior: A Case of FMCG Industry. Journal of Marketing Strategies, 3(1), 44 - 67.

Bhutada, N. S., Cook, C. L., \& Perri III, M. (2009). Consumers responses to coupons in direct-toconsumer advertising of prescription drugs. Health marketing quarterly, 26(4), 333-346.

Blattberg, R. C., \& Neslin, S. A. (1990). Sales promotion: Concepts, methods, and strategies. Prentice Hall.

Bryman, M. (1994). Promotional influence spurs buyers to try something new. Brandweek, 35(12), 32-34.

Dickson, P. R., \& Sawyer, A. G. (1984). Entry/exit demand analysis. ACR North American Advances.

Ehrenberg, A. S., Hammond, K., \& Goodhart, G. J. (1994). The after-effects of price-related consumer promotions. Journal of Advertising Research, 34(4), 11-22.

Familmaleki, M., Aghighi, A., \& Hamidi, K. (2015). Analyzing the influence of sales promotion on customer purchasing behavior. International Journal of Economics \& management sciences, 4(4), 1-6.

Fill, C. (2002). Marketing communications: Contexts, strategies, and applications. Financial Times/Prentice Hall.

Gardener, E., \& Trivedi, M. (1998). A communication framework to evaluate sales promotion strategies. Journal of Advertising Research, 38(3), 67-71.

Gilbert, D. C., \& Jackaria, N. (2002). The efficacy of sales promotions in UK supermarkets: a consumer view. International Journal of Retail \& Distribution Management. 
Kojima, S., \& Baba, M. (2001). Consumer behavior.

Kothari, C. R. (2004). Research methodology: Methods and techniques. New Age International.

Li, S., Sun, Y., \& Wang, Y. (2007). 50\% off or buy one get one free? Frame preference as a function of consumable nature in dairy products. The Journal of Social Psychology, 147(4), 413-421.

Mughal, A., Mehmood, A., Mohi-Ud-Deen, A., \& Ahmad, B. (2014). The impact of promotional tools on consumer buying behavior: a study from Pakistan. Journal of Public Administration and Governance, 4(3), 402-414.

Ndubisi, N. O., \& Moi, C. T. (2006). Awareness and usage of promotional tools by Malaysian consumers: the case of low involvement products. Management Research News.

Raji, R. A., Rashid, S., \& Ishak, S. (2019). The mediating effect of brand image on the relationships between social media advertising content, sales promotion content and behavioral intention. Journal of Research in Interactive Marketing.

Schofield, W. (1996). Survey sampling. Data collection and analysis, 25-55.

Shahzad, K., Bhatti, A., Islam, T., \& Javaid, A. (2020). Impact of Sales Promotion on Consumer Buying Behavior: A Case of Garments Industry of Pakistan. International Journal of Advanced Research in Engineering and Technology, 11(10).

Shamout, M. D. (2016). The impact of promotional tools on consumer buying behavior in retail market. International Journal of Business and Social Science, 7(1), 75-85.

Shi, Y. Z., Cheung, K. M., \& Prendergast, G. (2005). Behavioural response to sales promotion tools: a Hong Kong study. International Journal of advertising, 24(4), 469-489.

Silva-Risso, J. M., \& Bucklin, R. E. (2004). Capturing the effects of coupon promotions in scanner panel choice models. Journal of Product \& Brand Management.

Totten, J. C., \& Block, M. P. (1994). Analyzing sales promotion: text \& cases: how to profit from the new power of promotion marketing. The Dartnell Corporation.

Ward, J. C., \& Hill, R. P. (1991). Designing effective promotional games: Opportunities and problems. Journal of Advertising, 20(3), 69-81. 


\section{FURTHER READING}

Abebe, R. (2020). Effect Of Sales Promotion on Consumer Buying Behaviour: In Case of Coca Cola Soft Drink, Bahir Dar City (Doctoral dissertation).

Ashraf, M. G., Rizwan, M., Iqbal, A., \& Khan, M. A. (2014). The promotional tools and situational factors' impact on consumer buying behaviour and sales promotion. Journal of public administration and governance, 4(2), 179-201.

Chang, A. Y. P. (2017). A study on the effects of sales promotion on consumer involvement and purchase intention in tourism industry. Eurasia Journal of Mathematics, Science and Technology Education, 13(12), 8323-8330.

Daramola, G. C., Okafor, L. I., \& Bello, M. A. (2014). Sales promotion on consumer purchasing behaviour. International journal of business and marketing management, 2(1), 8-13.

Khan, M. A., Tanveer, A., \& Zubair, S. S. (2021). Impact of sales promotion on consumer buying behavior: a case of modern trade, Pakistan. Governance and Management Review, 4(1).

Obeid, M. Y. (2014). The effect of sales promotion tools on behavioral responses. International Journal of Business and Management Invention, 3(4), 28-31.

Osman, S., Fah, B. C. Y., \& Foon, Y. S. (2011). Simulation of sales promotions towards buying behavior among university students. International Journal of Marketing Studies, 3(3), 7888.

Rizwan, M., Irshad, Q., Ali, K., Nadir, M., \& Ejaz, M. (2013). Impact of sales promotional tools on purchase intention. International Journal of Management Sciences and Business Research, 2(1), 36-49.

Tong, D. Y. K., Lai, K. P., \& Tong, X. F. (2012). Ladies' purchase intention during retail shoes sales promotions. International Journal of Retail \& Distribution Management.

Ye, L. R., \& Zhang, H. H. (2014). Sales promotion and purchasing intention: Applying the technology acceptance model in consumer-to-consumer marketplaces. International Journal of Business, Humanities and Technology, 4(3), 1-5. 